\title{
Všímavost (mindfulness) jako potenciální nástroj rozvoje osobnosti sociálního pracovníka ${ }^{1}$ Michal Kaczor
}

\section{Úvod}

Rozvoj osobnosti sociálního pracovníka, resp. kontinuální péče o jeho celkové zdraví jsou při výkonu jeho profese klíčové. Na rozdíl od jiných profesí, kupř. řemeslných, přichází takřka permanentně do styku s živými bytostmi, tj. klienty. (Ne)zdravý duševní, potažmo tělesný stav, se pak zákonitě promítá do vzájemných interakcí. Jak zmiňuje Šuráňová, duševní zdraví je při výkonu profese sociálního pracovníka zásadní. Díky němu je disponován vykonávat ji dlouhodobě. Pokud mu ale schází nástroje ke kontinuální práci se sebou samým, mohou jej vnější tlaky pozvolna „drtit“. To potom zákonitě vede k postupnému vyhasínání mentální i tělesné energie. ${ }^{2}$ Bezesporu je tedy zapotřebí mít $\mathrm{k}$ dispozici nástroje $\mathrm{k}$ dlouhodobému rozvoji osobnosti. Jedním $\mathrm{z}$ takových může být námi pojednávaná všímavost (mindfulness). Ta totiž praktikujícím pomáhá ztišit rušnou mysl, více si uvědomovat přítomný okamžik, a tím méně „být uvězněn“ $v$ myšlenkách na minulost či budoucnost. To je efektivním prostředkem k vyrovnávání se nejen s úzkostmi a depresemi. V tom nejširším pojetí je všímavost vnímána jako prostředek vypořádávání se se stresem. Ten je v 21. století častou příčinou duševních i tělesných onemocnění. ${ }^{3}$

\section{Co je to všímavost čili mindfulness?}

Všímavost (mindfulness) pochází ze dvou klíčových zdrojů. Zaprvé z buddhistického směru a $\mathrm{z}$ něj vycházející psychologie, jež zahrnuje studium meditace a její působení na fungování lidského mozku. Zadruhé ze sociálního učení a dalších př́stupio v kognitivně behaviorální terapii, založených na zdưrazňování významnosti soustředění pozornosti na definované chování. ${ }^{4}$ Samotný pojem všímavost pochází z tradiční buddhistické psychologie dochované v eticko-psychologickém systému abhidhamma. Její rozvíjení je spojováno s praktikováním buddhistické meditace všímavosti a vhledu - satipatthana-vipassana. Člověk pozoruje vlastní mentální a tělesné procesy, aby poznal jejich pomíjivost, neuspokojivost a neosobní povahu. ${ }^{5}$ Významnou osobností v oblasti mindfulness byl Buddha. Ten se věnoval rozvoji

Článek je výstupem projektu specifického výzkumu GAJU č. 157/2016/H.

2 Srov. Veronika ŠURÁŇOVÁ, Využití všímavosti (mindfulness) v duševní hygieně pomáhajících profesí, in: SAPERE AUDE 2012: Vzdělávání a dnešní společnosti, Hradec Králové: Magnanimitas, 2012, s. 573.

Srov. Kate PICKERT, The Mindful Revolution: The Science of Finding Focus in a Stressed-Out, Multitasking Culture, TIME 3/2014, s. 42. Srov. Malcolm PAYNE, Modern Social Work Theory, Oxford: Oxford University Press, 2016, s. 167.

Srov. Jan BENDA, Meditace, všímavost a nové směry v KBT, Konfrontace - časopis pro psychoterapii 3/2006, s. 132 -135. 
a udržování všímavosti. Ve svém učení neopomínal ani výjimečný př́nos těchto postupů. ${ }^{6}$ Všímavost má svůj původ ve starodávných spirituálních praxích. V životě mnoha jedinců tvoří spiritualita, potažmo náboženské praktiky, klíčovou součást jejich existence. Mohou být rovněž významnými zdroji síly a zároveň plnit funkci nástrojů ke zvládání obtížných životních momentů.? Zdroji pojmu mindfulness jsou tedy spirituální směry východu i západu. Navíc, meditace byla důležitou praxí v hlavních světových náboženstvích, jako je hinduismus, konfucianismus, taoismus, buddhismus, judaismus, islám a křestanství. ${ }^{8}$

V současnosti je všímavost frekventovaným termínem, čemuž nepochybně přispívá překotné tempo postmoderní společnosti. O té dlouhodobě pojednává řada známých autorů - Bauman, Beck, Keller, Lipovetsky ad. ${ }^{9}$ Zákonitě se tedy zvyšuje poptávka po efektivních nástrojích, jež mají potenciál aktivizovat zahlcenou, rozrušenou mysl a udržovat zdraví v optimální kondici. Předmětem zájmu se stává i sociální práce jako jedna z pomáhajících profesí charakteristická vysokou zátěží kladenou na bedra sociálních pracovníků. ${ }^{10}$ Hick s Bienem upozorňují, že praktikující profesionálové z různých oborů založených na vztahu s klientem vykazují neobyčejný zájem právě o všímavost. Mj. z toho důvodu, že pozitivně ovlivňuje intervenci - jak na straně klienta, tak i profesionála. Ten může skrze všímavost např. kultivovat empatii a lásku, rozvíjet bytí v prítomnosti či poslechové dovednosti, zvyšovat schopnost odolávat stresu v pracovním i domácím prostředí či snížit pravděpodobnost rozvinutí syndromu vyhoření. ${ }^{11}$ Sociální pracovníci jsou „motorem“ čili nepostradatelným nástrojem efektivního pomáhajícího procesu. ${ }^{12}$ Je tedy zapotřebí věnovat pozornost takovým prostředkům, které rozvíjejí jejich osobnost a udržují duševní i tělesné zdraví v rovnováze. Jedním z nich je právě všímavost, o které pojednává tento článek. Ta má se sociální prací neopomenutelné styčné body. Pro obě je důležitou a ctěnou hodnotou jedincova individuální, žitá zkušenost v kontextu s jeho jedinečným životem. Navíc všímavost, stejně jako sociální práce, ve svém př́istupu zohledňuje péči o sebe, včetně sebe-akceptace, jakožto zásadní hodnoty. Stejně tak nehodnotící přístup je charakteristickým znakem jak pro všímavost, tak pro sociální práci. ${ }^{13}$ Péče o sebe je důležitým aspektem v praxi sociálního pracovníka. Ten může všímavost mnohostranně využít - k redukování stresu, navození pocitu klidu či zvýšení uvědomělosti atd. ${ }^{14}$ Všímavost je navíc kvalitou, která může pomoci sociálnímu pracovníkovi přistupovat ke všem situacím týkajícím se jeho praxe s jasností, soustředěností a soucitem. ${ }^{15}$

Všímavost bývá obvykle definována jako „vědomí o jednotlivých momentech“ či „zaměřování pozornosti na přítomný okamžik, bez posuzování a hodnoceni'“ a podporuje pozornost ke každému

6 Srov. Michael CHASKALSON, Mindfulness za 8 týdnů, Praha: BizBooks, 2017, s. 18.

7 Srov. Marsha M. LINEHAN, DBT Skills Training Manual, New York: Guilford Press, 2015, s. 156.

8 Srov. Lloyd RIDGEON, Major Religions of the World, New York: Taylor \& Francis, 2003.

9 Srov. Zygmunt BAUMAN, Úvahy o postmoderní době, Praha: SLON, 2006; Ulrich BECK, Riziková společnost: Na cestě k jiné moderně, Praha: SLON, 2011; Jan KELLER, Posvícení bezdomovců: Úvod do sociologie domova, Praha: SLON, 2013; Gilles LIPOVETSKY, Hypermoderní doba: Od požitku k úzkosti, Praha: Prostor, 2013.

10 Srov. Jitka GÉRINGOVÁ, Pomáhající profese: Tvořivé zacházení s odvrácenou stranou, Praha: Triton, 2011, s. 36; Jiří JANKOVSKÝ, Etika pro pomáhající profese, Praha: Triton, 2003, s. 157-165; Oldřich MATOUŠEK, Metody a rízení sociální práce, Praha: Portál, 2008, s. 5160; Zdeněk MLČÁK, Potenciální zdroje stresu v sociální práci a jejich zvládání, Sociální práce / Sociálna práca 3/2005, s. $124-137$.

11 Srov. Steven F. HICK - Thomas BIEN, Mindfulness and the Therapeutic Relationship, New York: The Guilford Press, 2010 , s. 4.

12 Srov. Andrej MÁTEL - Milan SCHAVEL - Pavel MÜHLPACHR - Tibor ROMAN, Aplikovaná etika v sociální práci, Brno: Institut mezioborových studií, 2010, s. 93-94; Karel KOPǨIVA, Lidský vztah jako součást profese, Praha: Portál, 2006, s. 94.

13 Srov. Francis J. TURNER, Social Work Treatment: Interlocking Theoretical Approaches, Oxford: Oxford University Press, 2017, s. 335336.

14 Srov. Aneesha KELLY - Ifeoma OKOLO, Mindfulness Meditation as a Self-Care Practice in Social Work, in: Master of Social Work Clinical Research Papers, Minnesota: School of Social Work, 2016, s. 2.

15 Srov. Edward R. CANDA - Leola D. FURMAN, Spiritual Diversity in Social Work Practice: The Heart of Helping, Oxford: Oxford University Press, 2010, s. 362. 
pohybu, dechu, cítění a myšlení. ${ }^{16}$

Jeden z průkopníků mindfulness, doktor Jon Kabat-Zinn, uvádí, že:

„Všímavost je uvědomělost, utvářená pozorností nepřetržitým a konkrétním způsobem: záměrně, $\mathrm{v}$ prítomném okamžiku, objektivně (nekriticky). Je jedním ze způsobů meditace, pokud meditaci chápeme jako: 1. Systematické usměrňování naší pozornosti a energie, 2. Tím ovlivňování a přeměna našich zkušeností, 3 . V průběhu rozpoznávání celého spektra lidství a 4. Naše vztahy s dalšími lidmi a světem. ${ }^{\text {"17 }}$

Rovněž zmiňuje, že všímavost je mocným nástrojem sebeporozumění jedince a klíčem ke komplexnímu zlepšování jeho zdraví. ${ }^{18}$ Hassonová konkretizuje, co je jádrem tohoto př́stupu: „Mindfulness může člověku pomoci přehlušit ubíjející proud myšlenek, které se mu neustále honí hlavou. " ${ }^{19}$ Dodává, že si lze techniku všímavosti lépe představit v analogii ke komentovanému sportovnímu utkání v televizi. Pokud divák vypne zvuk (tj. slovní komentář zápasu), lze utkání vnímat daleko bezprostředněji. Podobně je to i se subjektivním komentářem myšlenek k prožitým objektivním zážitkům a zkušenostem. ${ }^{20}$ Sinclair a Seydel zase přirovnávají všímavost $\mathrm{k}$ jakémusi opaku života na „autopilota“. Umožňuje přiblížit se vnitřnímu klidu a stabilitě a zároveň je posilovat a kultivovat. Všímavost pak v konečném důsledku pomáhá např. redukovat stres, relaxovat, vypěstovat si odolnost vůči stresu, zlepšit výkonnost a efektivitu práce, využívat přirozených zdrojů fyzické a psychické energie či otevř́t se tvořivosti. ${ }^{21}$

Zdá se tedy, že všímavost je značně efektivním nástrojem nejen v oblasti vyrovnávání se s pracovní zátěží, kterou generují pomáhající profese. Rovněž je uplatnitelná v komplexním rozvoji osobnosti sociálních pracovníků. Následující kapitola interpretuje výsledky některých realizovaných vědeckých výzkumů.

\section{Co říkají o účinnosti všímavosti některé realizované vědecké výzkumy}

Výzkumů v oblasti všímavosti vznikl nespočet. $Z$ důvodu omezeného prostoru budou uvedeny pouze některé $\mathrm{z}$ nich, které mohou čtenáři sloužit jako určitá referenční skupina demonstrující účinnost mindfulness nejen v sociální práci, ale i v nejrůznějších profesích, jejichž jádrem je práce s lidmi. Výzkumy ukazují, že prostřednictvím všímavosti může člověk postupně dosáhnout žádoucích výsledků, jako např. přijetí, schopnost nechat věci být tak, jak jsou, nehodnotící postoj či důvěra $\mathrm{v}$ sebe sama. V̌símavost usnadňuje změny ve vnitřním a vnějším světě nejen u sociálních pracovníků, ale rovněž u klientů. ${ }^{22}$

Kelly a Okolo ve svém výzkumu věnovaly pozornost sociálním pracovníkům a jejich péči o sebe. Zajímalo je, zda intervence v podobě 6týdenního tréninku všímavosti bude mít pozitivní vliv na jejich životy. Výsledky ukázaly, že tento zásah do péče sociálních pracovníků o sebe zvýšil míru jejich sebeuvědomění a uspokojení v oblasti soucitu. Naopak se snížila pravděpodobnost vzniku

16 Srov. Robyn LYNN - Jo MENSINGA, Social Workers' Narratives of Integrating Mindfulness into Practice, Journal of Social Work Practice 3/2015, s. 255-256.

17 Jon KABAT-ZINN, Mindfulness for Beginners: Reclaiming the Present Moment - and Your Life, Colorado: Sounds True, 2012 , s. 1.

18 Srov. Jon KABAT-ZINN, Život samá pohroma: Jak čelit stresu, nemoci a bolesti pomocí moudrosti těla a mysli, Brno: Jan Melvil Publishing, 2016.

19 Gill HASSON, Technika mindfulness: Jak se vyvarovat duševní prokrastinace prostřednictvím všímavosti a bdělé pozornosti, Praha: Grada, 2015, s. 28.

20 Srov. Tamtéž

21 Srov. Michael SINCLAIR - Josie SEYDEL, Všímavost: Cesta pro zklidnění mysli pro ty, co nestíhají, Praha: Grada, 2015, s. 26.

22 Srov. Liora BIRNBAUM - Aiton BIRNBAUM, Mindful Social Work: From Theory to Practice, Journal of Religion \& Spirituality in Social Work: Social Thought 1-2/2008, s. 87-104. 
syndromu vyhoření či sekundárního traumatického stresu. Výzkum tedy potvrdil, že zařazování praktik všímavosti do každodenního života sociálních pracovníků může přinést velký prospěch. ${ }^{23}$ V dalším výzkumu byly realizovány dvě studie. První z nich sledovala, zda je krátkodobá intervence prostřednictvím všímavosti u profesionálů pracujících s lidmi (zdravotní sestry) účinnější, než intervence prostř̌ednictvím tradiční relaxace. Výsledky ukázaly, že jsou účinné obě dvě, a to zejména v oblasti uvolnění a životní spokojenosti. U respondentů praktikujících všímavost byla navíc zvýšena odolnost vưči emocionálnímu vyčerpání. Ve druhé studii vykazovali respondenti (pedagogičtí praktikanti), kteří se zúčastnili Mindfulness-Based Wellness Education (MBWE), signifikantně vyšší hodnoty v oblastech všímavosti, spokojenosti se životem či sebejistoty v učení. ${ }^{24}$

McGarrigle a Walsh ve svém výzkumu sledovali účinnost 8týdenního kontemplativního tréninku. Zajímaly je následující oblasti: zvyšování péče o sebe, úroveň všímavosti a copingové strategie, a to u 12 respondentů, kteří ve svém zaměstnání pracují s lidmi. Ukázalo se, že v průběhu intervence všímavost signifikantně vzrostla a úroveň stresu se naopak značně snížila. Tímto bylo doloženo, že díky praktikám všímavosti může sociální pracovník zvýšit nejen péči o sebe, ale zákonitě ovlivnit také vztah s klienty, resp. službu jako takovou. ${ }^{25}$

Pozoruhodný výzkum prováděla Birnbaum, která se věnovala studentům sociální práce. Upozornila na známou skutečnost, že se pravidelně setkávají s emočním stresem, a zároveň jsou nuceni, aby naplňovali očekávání - a to jak akademického prostředí, tak oboru sociální práce jako takového. Mohou se tedy v důsledku toho často cítit fyzicky a emocionálně přetíženi. Potřebují adekvátní čas a prostor $\mathrm{k}$ tomu, aby tyto různorodé zážitky plně a efektivně zpracovali. Skupina účastnící se výzkumu se v průběhu 8 týdnů setkávala s technikou všímavosti, která cílila na zvýšení sebevědomí a emocionální podpory při vypořádávání se s akademickými stresory. Závěry výzkumu ukázaly, že studenti byli schopni získat nové znalosti o sobě, rovněž zažít autonomii v učení se, znovu-obnovení a regulaci psychické kondice a získat náhled na své profesionální sebepojetí. ${ }^{26}$ Studentům sociální práce, konkrétně v posledním ročníku studia, se věnoval rovněž výzkum, který realizovali Howie, Innes a Harvey. Ti v rámci výzkumu využili mindfulness trénink vycházející ze známého MBSR programu (Mindfulness-Based Stress Reduction) doktora Jona Kabata-Zinna. Zpětná vazba studentů pak prokázala řadu osobnostních i profesních benefitů. Ty mj. zahrnovaly podporu psychické odolnosti a kompetencí k tomu být vědomý. ${ }^{27}$ Napoli a Bonifas sledovali absolvující studenty sociální práce, kteří se zúčastnili 16týdenního kurzu, soustř̌edícího se na rozvoj péče o sebe a profesní rozvoj, a to pomocí formálních a neformálních strategií praktikování všímavosti. Byly testovány čtyři oblasti: vědomé jednání, pozorování, akceptace bez posuzování, popisování. Výsledky ukázaly, že studenti výrazně zvýšili využívání všímavosti v prvních třech oblastech. ${ }^{28}$

Byla rovněž prokázána souvislost tréninku všímavosti s emoční inteligencí. Výzkum, který provedl Li-Chuan Chu, ukázal pozitivní př́nosy meditace v souvislosti s emoční inteligencí (EI),

23 Srov. Aneesha KELLY - Ifeoma OKOLO, Mindfulness Meditation as a Self-Care Practice in Social Work, in: Master of Social Work Clinical Research Papers, Minnesota: School of Social Work, 2016.

24 Srov. Patricia A. POULIN - Corey S. MACKENZIE - Geoffrey SOLOWAY - Eric KARAYOLAS, Mindfulness Training as an EvidenceBased Approach to Reducing Stress and Promoting Well-Being among Human Services Professionals, International Journal of Health Promotion and Education 2/2008, s. 72-80.

25 Srov. Tessa MCGARRIGLE - Christine A. WALSH, Mindfulness, Self-Care, and Wellness in Social Work: Effects of Contemplative Training, Journal of Religion \& Spirituality in Social Work: Social Thought 3/2011, s. 212-233.

26 Srov. Liora BIRNBAUM, The Use of Mindfulness Training to Create an ,Accompanying Place' for Social Work Students, Social Work Education: The International Journal 8/2008, s. 837-852.

27 Srov. Jayne HOWIE - Debbie INNES - Paul HARVEY, Promoting Conscious Competence by Introducing Mindfulness to Social Work Students, The Journal of Practice Teaching and Learning 1/2016, s. 88-104.

28 Srov. Maria NAPOLI - Robin BONIFAS, From Theory Toward Emphatic Self-Care: Creating a Mindful Classroom for Social Work Students, Social Work Education: The International Journal 6/2011, s. 635-649. 
vnímáním stresu a negativním mentálním zdravím. Bylo pozorováno 351 dospělých, pracujících na plný úvazek, s různými zkušenostmi v meditaci. Potvrdilo se, že respondenti s větší meditační zkušeností vykazovali vyšší míru emoční inteligence (EI) a méně vnímali stres a negativní duševní zdraví. Meditační trénink tedy podle této studie komplexně zlepšuje stav člověka. ${ }^{29}$

Výzkum Shiera a Grahama analyzoval subjektivní well-being u sociálních pracovníků ve vztahu k jejich stavu všímavosti. Z počátečního šetření 700 sociálních pracovníků bylo vybráno 13, kteří vykazovali nejvyšší skóre subjektivního well-beingu. Ti potvrdili, že všímavost ovlivnila jejich celkový subjektivní well-being. Též naznačili, že existují určité aspekty jejich života, které potřebují k tomu, aby mohli být všímaví. Mezi ně patří: reflektování a rozvíjení osobní identity, přemýšlení o otázkách týkajících se kontroly a otevřenosti, reflektování klíčových okamžiků v životě a zachovávání rovnováhy mezi osobním a pracovním životem. ${ }^{30}$

Doxtdator shrnuje svůj výzkum slovy, že všímavost může sociálním pracovníkům poskytnout prostředky k návratu na místo autenticity a smyslu, vrátit pocit smyslu jejich povolání, který je mnohdy k vykonávání této profese přivedl. ${ }^{31}$

Výzkumů soustředěných na všímavost v oboru sociální práce stále přibývá a zdá se, že výzkum všímavosti a jejího mnohostranně pozitivního působení na osobnost sociálního pracovníka se těší v různých koutech světa velkému zájmu. Jedná se však zejména o výzkumy zahraniční. V České republice je ale pro všímavost v sociální práci velký prostor, což bude nastíněno v následující kapitole. Nutno dále podotknout, že výsledky zahraničních výzkumů mohou na čtenáře působit veskrze optimisticky. To je na jednu stranu příznivým signálem, podporujícím tvrzení, že všímavost může být jednou z těch metod, jež přispívají k mentálnímu zklidnění některých jedinců. Na stranu druhou však prezentované výsledky zahraničních výzkumů v žádném případě nelze pouze nekriticky přijímat. Je zapotřebí se hlouběji věnovat jejich metodologickým limitům a dalším faktorům, které potenciálně zkreslují výstupy. To je bohužel již nad kapacitu tohoto článku. Nicméně, v kapitole s názvem Odvrácená tvář mindfulness aneb k možným rizikům všímavosti jsou přiblíženy alespoň některé kritické studie související s praktikováním všímavosti.

\section{Současný stav na poli sociální práce jako prostor pro všímavost}

Současná sociální práce se odehrává v rámci významných společenských proměn, které s sebou přinesla postmoderní společnost. Tu lze charakterizovat jako historicky významný moment, kdy došlo $\mathrm{k}$ rozmělnění institucionálních zábran, jež do té doby fungovaly jako otěže limitující jedince před jeho vlastní emancipací. V důsledku toho dostalo více prostoru zejm. budování seberealizace. Ruku v ruce s tím došlo k značnému oslabení systémů, které původně sloužily k socializaci jedinců a dávaly jejich životům jakýsi „pevný rámec“ ${ }^{32}$ To odkazuje na výraznou společenskou rozpolcenost, resp. různorodost a variabilitu sociálních problémů, se kterými se sociální pracovník potýká. Musí být schopný pružně reagovat na měnící se společnost, resp. nové společenské proměny a souvislosti. ${ }^{33}$ To samo o sobě je spojeno s četnými zátěžovými faktory, které musí při výkonu profese absorbovat, aby ochránil své zdraví, at už se jedná o to mentální či tělesné.

29 Srov. Li-Chuan CHU, The Benefits of Meditation vis-à-vis Emotional Intelligence, Perceived Stress and Negative Mental Health, Stress \& Health 2/2010, s. 169-180.

30 Srov. Micheal L. SHIER - John R. GRAHAM, Mindfulness, Subjective Well-Being, and Social Work: Insight into their Interconnection from Social Work Practitioners, Social Work Education: The International Journal 1/2011, s. 29-44.

31 Srov. Mary L. DOXTDATOR, Mindfulness: Helping Social Workers Bring Themselves Home, Ontario: McMaster University, 2012.

32 Srov. Gilles LIPOVETSKY, Hypermoderní doba: Od požitku k úzkosti, Praha: Prostor, 2013, s. 18-22.

33 Srov. Jiřina ŠIKLOVÁ, Medailón, Sociální práce / Sociálna práca 2/2010, s. 2.; Karel PAULÍK, K otázce zvládání pracovních nároků v sociální práci, Kontakt - časopis pro ošetřovatelství a sociální vědy ve zdraví a nemoci 2/2006, s. 292-293. 


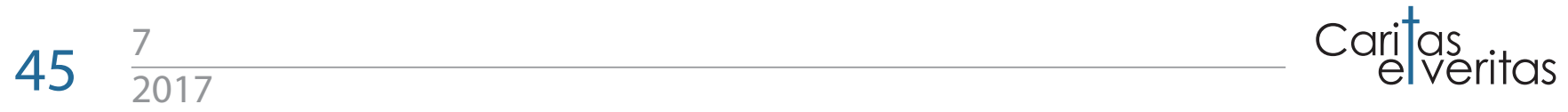

S ohledem na celkovou zátěž je zásadní především vztah sociálního pracovníka a klienta. Ten je jádrem pomáhajícího procesu. Požadavky kladené na sociální pracovníky v souvislosti s podporou lidí (resp. klientů) v různých životních situacích a okolnostech mohou přispět k vysokým úrovním stresu a rovněž syndromu vyhoření. ${ }^{34} J a k$ zmiňuje Paulík, součástí tohoto vztahu je nejen odborná pomoc při řešení problémových situací přesahujících klientovu aktuální adaptivní kapacitu, ale mj. též empatický př́stup ke klientům, snaha jim porozumět a vypořádávání se s rozmanitými rušivými vlivy, jako jsou např. kumulace pracovních úkolů, konflikt profesních rolí, byrokracie, riziko napadení klientem, nedostatečné ohodnocení práce, nedostatky v legislativě apod. ${ }^{35}$ Společným jmenovatelem pomáhajícího procesu - tedy tím, co spojuje sociální pracovníky - je to, že vstupují do kontaktu s druhými lidmi. Právě všímavost jim může dát do rukou účinné nástroje, prostřednictvím kterých snáze minimalizují zátěž spojenou s jejich profesí. Mimo to se sociálním pracovníkủm otevírá cesta k lepšímu zpracování vlastního prožívání a prohloubení porozumění problémům druhých lidí, včetně zvýšení osobních kompetencí pro práci s nimi - empatie a opravdovosti. ${ }^{36}$ Mindfulness může být kreativní a použitelný nástroj pro všechny ty, kteři jej chtějí ve svůj prospěch využít - a to způsobem, který je pro ně efektivní. Dovede významně snížit hladinu stresu a daleko efektivněji balancovat mezi požadavky, kterým člověk v životě čelí. Sociální pracovníci mohou všímavost využívat například pro předcházení syndromu vyhoření a zvyšování uvědomělosti. ${ }^{37}$ Všímavost zahrnuje orientaci na současnou chvíli. Ta umožňuje lépe zaznamenávat to, co se s člověkem děje právě v tuto chvíli, a efektivněji tak předcházet obvyklé tendenci dělat si starosti s minulostí, anebo se zaobírat tím, co přinese budoucnost. Orientace na současný okamžik může přinést vnitřní klid a usnadnit pozornější př́ístup $\mathrm{k}$ práci s ostatními. Ten je v sociální práci velmi důležitý. Všímavost též zahrnuje postupy k posilování sebelásky a sebepřijetí. Přijímáním toho, co se děje $\mathrm{v}$ přítomném okamžiku, se může významně změnit vztah k negativním emocím a stavům mysli. To vše pak umožňuje sociálním pracovníkům s laskavostí o sebe pečovat. To je zásadním předpokladem $\mathrm{k}$ tomu, aby se účinně starali o ostatní. ${ }^{38}$ Bylo prokázáno, že v sociální práci může být orientace na př́tomný okamžik př́nosem jak na úrovni jednotlivce, tak i skupiny či komunity, zejm. v oblastech pěstování zvýšené pozornosti, zvýšeného sebeuvědomění, pěstování empatie a soucitu, vnitřního klidu a míru, většího vhledu a transformativních cest, jak žít a být. ${ }^{39}$

Benefitů, které může poskytnout všímavost je však ještě celá řada, kupř.: zvýšení pracovního výkonu, resp. efektivity práce, zlepšení komunikace a řešení problémů, zvýšení koncentrace a soustředění, zvýšení schopnosti zvládat konflikty, dosažení rovnováhy a odolnosti na pracovišti i v domácím prostředí, zlepšení srozumitelnosti a posílení kreativního myšlení, podporování psychické a fyzické pohody, snižování hladiny stresu, předcházení syndromu vyhoření a emocionálnímu vyčerpání, redukování automatických a navyklých reakcí (resp. schopnost rozhodovat se více uvědoměle), redukování chronických bolestí, zlepšení energetické hladiny, zvýšení kontroly v př́ípadě dlouhodobých úzkostných poruch, zlepšení profesionální praxe

34 Srov. MCGARRIGLE - WALSH, Mindfulness..., s. 212.

35 Srov. PAULÍK, K otázce..., s. 293.; Srov. Jana STEJSKALOVÁ, Krize sociální práce aneb máme to ještě ve svých rukou?, Sociální práce / Sociálna práca 3/2014, s. 11.

36 Srov. Karel HÁJEK, Satiterapie vybaví sociálního pracovníka nástroji, kterými může minimalizovat zátěž z pomáhající profese, Sociální práce / Sociálna práca 4/2008, s. 40.

37 Srov. Allison L. LEONARD, Breathe In, Breathe Out: Utilizing Mindfulness in Social Work Practicum, in: Undergraduate Honors Theses, Utah: Utah State University, 2012, s. 2.

38 Srov. Steven F. HICK, Mindfulness and Social Work: Paying Attention to Ourselves, Our Clients, and Society, in: Mindfulness and Social Work, Chicago: Lyceum Books, 2009, s. 24.

39 Srov. LYNN - MENSINGA, Social Workers' Narratives..., s. 256 
a pracovních vztahů. ${ }^{40}$ Navíc, sociální pracovník praktikující všímavost si může být díky ní více vědom těch věcí, které jsou na jeho pracovišti dysfunkční, a též k nim zaujmout patřičný kritický postoj. ${ }^{41}$

V souvislosti s jmenovanými benefity, resp. pozitivními důsledky je zapotřebí mít na paměti to, že praxe všímavosti od sociálního pracovníka vyžaduje také jisté investice. V případě kurzů všímavosti (MBSR, MBCT) - jak bude přiblíženo v další kapitole - je základním předpokladem navštěvovat pravidelná setkávání v průběhu osmi týdnů trvání kurzu. Samozř̀mostí je pak každodenní plnění strukturovaného plánu domácí praxe, na který si musí frekventant pravidelně vyhrazovat čas. Pokračování v praxi se očekává rovněž po skončení kurzu. Jak zmiňuje Kabat-Zinn, základní pilíře praxe všímavosti tvoří sedm postojových faktorů - neposuzování, trpělivost, mysl začátečníka, důvěra, neusilování, přijetí, schopnost nechat jít. Pouze pravidelnou praxí mohou být tyto faktory adekvátně kultivovány. ${ }^{42}$

Výše zmíněné ukazuje, že všímavost může být pro sociální pracovníky komplexním nástrojem k rozvoji jejich osobnosti, a to především za předpokladu, že sociální pracovník je ochoten investovat potřebné úsilí do rozvíjení mindfulness praxe. Níže jsou uvedeny konkrétní možnosti, jak mohou sociální pracovníci všímavost rozvíjet, zdokonalovat a udržovat.

\section{Možnosti, prostřrednictvím kterých mohou sociální pracovníci rozvíjet, zdokonalovat a udržovat všímavost}

Předně je nutno si uvědomit, že existují různé přístupy v trénování všímavosti. V této kapitole budou uvedeny dva hlavní, mezi kterými si sociální pracovník může zvolit ten, který je mu nejbližší, a využít jej k rozvoji svojí osobnosti, a to nejen ve smyslu budování psychické odolnosti, koncentrace a soustředění. Může z něj čerpat také pestré benefity, které byly nastíněny v předchozích kapitolách. Rovněž Payne ve své publikaci Modern Social Work Theory uvádí ve výčtu, vedle několika dalších, tyto dvě ucelené formy trénování všímavosti. ${ }^{43}$ Jejich výhodou je, že jsou použitelné obousměrně - tj. jak při rozvoji osobnosti sociálního pracovníka, tak při práci s rozmanitými nesnázemi jeho klientů, jako např. práce s depresemi, nízkým sebevědomím, přejídáním apod. Sociální pracovník však nemusí nutně využívat ucelené, propracované a osvědčené kurzy MBSR, MBCT (uvedené níže) nebo jiné „odrůdy“ tréninků všímavosti. Může se na tuto cestu vydat „svépomocí. Existuje totiž spousta odborných publikací, jako např. dílo Jona Kabata-Zinna Život samá pohroma: Jak čelit stresu, nemoci a bolesti pomocí moudrosti těla a myslit ${ }^{4}$, které jsou konstruovány jako určitý manuál (resp. alternativa) tréninku všímavosti pro samouky. Těch mohou využít zejm. jedinci, kteří nechtějí vstupovat do placených a odborně vedených kurzů.

- MBSR (Mindfulness-Based Stress Reduction) - byl založen v 70. letech 20. století ve Spojených státech amerických. Používal se zejména $\mathrm{v}$ klinickém prostředí, a to u jedinců se širokou škálou diagnóz - od přemíry stresu, přes závislosti na návyko-

40 Srov. () SSSC News, Bringing Mindfulness to Social Work (on-line), dostupné na: http://ssscnews.uk.com/2014/11/27/bringingmindfulness-workplace-social-work, citováno dne 1. 7. 2017.; Srov. Louise GRANT - Gail KINMAN, Developing Resilience for Social Work Practice, UK: Palgrave, 2014.

41 Srov. Jim ROGERS - Lucy BRIGHT - Helen DAVIES, Social Work with Adults, UK: Sage Publications, 2015.

42 Srov. Jon KABAT-ZINN, Full Catastrophe Living: Using the Wisdom of Your Body and Mind to Face Stress, Pain and Illness, New York: Batam Books, 2013, s. 21.

43 Srov. PAYNE, Modern Social Work..., s. 167.

44 Srov. KABAT-ZINN, Život samá pohroma: Jak čelit stresu, nemoci a bolesti pomocí moudrosti těla a mysli, Brno: Jan Melvil Publishing, 2016. 
vých látkách, až po chronickou bolest. MBSR využívá výzkumy ověřeného 8týdenního sylabu, vyvinutého Jonem Kabatem-Zinnem. ${ }^{45}$ Frekventanti absolvují trénink v oblasti sebepozorování a zvládání stresu za použití formálních technik snižujících stres, jako je např̀ jóga, a jsou vedení $\mathrm{k}$ tomu, aby si byli více vědomi stresorů $\mathrm{v}$ každodenních činnostech. Skupinová diskuse $\mathrm{v}$ rámci tréninku se pak využívá $\mathrm{k}$ podpoře individuálního učení. ${ }^{46}$

- MBCT (Mindfulness-Based Cognitive Therapy) - MBSR a MBCT sdílejí kolem 80 procent obsahu - úzce spolu tedy souvisejí. Hlavní rozdíl mezi nimi spočívá v tom, že MBSR je zaměřen na mentální nesnáze (jako napřs stres, úzkost, strach) obecně a MBCT se více soustředí na to, jak člověk uvažuje, resp. myslí. Trénink MBCT byl vytvořen v roce 1990 ve Velké Británii Zindalem Segalem, Markem Williamsem a Johnem Teasdalem. Ti MBCT založili se záměrem pomáhat lidem s depresí (v klinickém prostředí). MBCT př́stup spojuje všímavost $s$ prvky kognitivně behaviorální terapie a je tedy, na rozdíl od MBSR, více zaměřen na pomoc lidem zjistit, jak efektivně pracovat se svou myslí. ${ }^{47}$ Jinými slovy, klade důraz na myšlení a priority v životě, oproštěné od škodlivého stresu. ${ }^{48}$

Obecnou podobu, at už MBSR či MBCT kurzu, tvoří osm dvouapůlhodinových sezení v průběhu 8 týdnů trvání (tj. každý týden jedno), s dodatečným dnem všímavosti po uplynulých 6 týdnech kurzu. Patří sem rovněž strukturovaný plán domácí praxe, který má pro účastníky kurzu zásadní význam. Ten typicky zahrnuje 45 minut denně věnovaných formální praxi všímavosti (body scan, resp. skenování těla, meditace vsedě či v chůzi, jóga), včetně některých neformálních praktik, jako je pozorování a zaznamenávání zkušeností/pocitů v průběhu celého programu. Účastníci jsou před vstupem do kurzu požádáni, aby vyplnili obecné dotazníky, a stejně tak je obvykle realizován předvstupní pohovor s lektorem kurzu. ${ }^{9}{ }^{9}$

Sociální pracovník má tedy $\mathrm{k}$ dispozici ucelené a strukturované výcviky mindfulness, prostřednictvím kterých může všímavost pod odborným dohledem lektora rozvíjet, pěstovat a udržovat. $\mathrm{V}$ opačném prŕípadě tak může učinit sám, prostřednictvím některých knižních zdrojů, resp. „manuálů všímavosti“ pro samouky.

\section{Odvrácená tvář mindfulness aneb $\mathrm{k}$ možným rizikům všímavosti}

Nesporné výhody praktikování všímavosti jsou neustále dokládány prostřednictvím probíhajících výzkumů. Některé $\mathrm{z}$ nich byly $\mathrm{v}$ tomto textu představeny. $\mathrm{Na}$ jednu stranu je $\mathrm{k}$ dispozici nespočet prokázaných pozitivních důsledků mindfulness praxe, na stranu druhou je však jenom zlomek pozornosti věnován potenciálním rizikům. $\mathrm{O}$ těch navíc v současné době neexistuje mnoho vědeckých poznatků. ${ }^{50}$

V roce 2009 poukázal vědecký tým Kathleen Lustyk na možná rizika plynoucí z praktikování různých druhů meditace (včetně mindfulness meditace). Ve svém článku sumarizovali studie, které udaly nepř́íznivé vedlejší účinky u praktikujících frekventantů. Mezi tyto patří např. depersonalizace (pocit odpojení od duševních procesů nebo těla), psychóza (ztráta kontaktu s realitou) s blu-

\footnotetext{
5 Srov. Shamash ALIDINA - Juliet ADAMS, Mindfulness at Work Essentials for Dummies, USA: John Wiley \& Sons, 2014. 6 Srov. PAYNE, Modern Social Work..., s. 167.

7 Srov. Shamash ALIDINA - Juliet ADAMS, Mindfulness at Work Essentials for Dummies, USA: John Wiley \& Sons, 2014.

8 Srov. PAYNE, Modern Social Work..., s. 167.

9 Srov. Terry HYLAND, Mindfulness and Learning: Celebrating the Affective Dimension of Education, UK: Springer, 2011, s. 56.

50 Srov. () Oxford Mindfulness Centre, Is Mindfulness Safe? (on-line), dostupné na: http://oxfordmindfulness.org/news/is-mindfulnesssafe, citováno dne 3. 7. 2017.
} 
dy, halucinacemi a neorganizovaným projevem, pocity úzkosti, zvýšené riziko záchvatů, ztráta chuti k jídlu nebo nespavost. Sám výzkumný tým však zmiňuje, že doposud nebyly rozpracovány postupy screeningu praktikujících účastníků, bezpečnostní mantinely výzkumů či standardy pro výcvik výzkumných pracovníků. ${ }^{51}$ Výstupy tedy mohou být určitým způsobem zkreslené. Je navíc zapotřebí důsledně zohledňovat zdravotní stav účastníků. Ten pochopitelně hraje ve vyvolávání nežádoucích psychických a tělesných stavů velkou roli. Autoři výzkumu obzvláště zmiňovali např̀ osoby s PTSD (posttraumatická stresová porucha), u nichž je namístě dbát zvýšené opatrnosti. $S$ dalším zajímavým poznatkem přišel odborník na spiritualitu a zdraví doktor David Treleaven. Ten popsal skutečnost, že trvalá pozornost k tělu, související se všímavostí, může vést k tzv. „kontemplativní disociaci“. Jedná se o určitou absenci propojenosti myšlenek, emocí a tělesných pocitů. Ta podle něj nastává v okamžiku, kdy se jedinec právě prostřednictvím přítomného okamžiku (resp. soustředěností na mentální a tělesné stavy) dotkne minulých fyzických či psychických traumat, která doposud nebyla adekvátně zpracována. To jej uvrhne do bolesti, jež může dlouho přetrvávat a ze které je komplikované se vymanit. ${ }^{52}$

Výše zmíněné tedy napovídá, že je namístě se více věnovat úskalím, resp. rizikům spojeným s praktikováním všímavosti. Vzhledem $\mathrm{k}$ nedostatku relevantních vědeckých poznatků nelze o rizicích zatím mnoho vyvozovat. Některá z nich však byla v této kapitole uvedena.

\section{Závěr}

Všímavost (mindfulness) je stále častěji předmětem různých výzkumů a je obvykle využívána zejm. v psychologii či medicíně - v poslední době se však dostává do popředí též v literatuře z oboru sociální práce. Zde je všímavost a zájem o ni relativně novým fenoménem, jenž si rozhodně zaslouží hlubší pozornost a další zkoumání. V textu byla představena všímavost jako potenciální a účinný nástroj rozvoje osobnosti sociálního pracovníka, a to skrze interpretace jednotlivých autorů, kteří o všímavosti pojednávají. Ta bývá označována za jakousi „posilovnu mysli“ či „mentální fitness“ a je jistou dobrodružnou cestou vedoucí k sebepoznání a seberozvoji. Tedy přesně k tomu, co je předpokladem rozvinuté a zdravé osobnosti sociálního pracovníka. ${ }^{53}$

Dále byla účinnost mindfulness demonstrována na existujících výzkumech souvisejících se sociální prací, které ukazují, že trénink všímavosti prokazatelně přináší benefity do osobního i profesního života jedince. Nelze opomenout ani skutečnost, že na sociální pracovníky jsou kladeny vysoké nároky a profese sociální práce sama o sobě je spojena s vysokou mírou zátěže. ${ }^{54}$ Jsou to např. požadavky kladené na sociální pracovníky v souvislosti s podporou klientů v různorodých životních situacích a okolnostech, které mohou přispět k vysokým úrovním stresu a rovněž syndromu vyhoření. ${ }^{55} \mathrm{~V}$ souhrnu lze konstatovat, že neustále rostou požadavky na výkon profese (ze strany společnosti, státu, klientů), ale permanentní omezování finančních prostřredků, nedostatečné platové ohodnocení sociálních pracovníků, nízká prestiž oboru, nedostatky v legislativě, resp. její nestálost ad. (o nichž píši např. Paulík a Stejskalová) s tím vůbec nejdou ruku v ruce. ${ }^{56}$

51 Srov. Kathleen B. LUSTYK - Neharika CHAWLA - Roger S. NOLAN - Alan MARLATT, Mindfulness Meditation Research: Issues of Participant Screening, Safety Procedures, and Researcher Training, Advances 1/2009, s. 20-30.

52 Srov. David TRELEAVEN, Meditation, Trauma, and Contemplative Dissociation, Somatics: Magazine-Journal of the Mind/Body Arts and Sciences 2/2010, s. 20-22.

53 Srov. Vidyamala BURCH - Danny PENMAN, Meditace pro zdraví: Praktický průvodce pro zvládání bolesti, nemocí a stresu pomocí všimavosti, Praha: Grada, 2016, s. 198.

54 Srov. GÉRINGOVÁ, Pomáhající profese, s. 36.; JANKOVSKÝ, Etika, s. 157-165.; MATOUŠEK, Metody, s. 51-60.; Zdeněk MLČÁK, Potenciální zdroje stresu v sociální práci a jejich zvládání, Sociální práce / Sociálna práca 3/2005, s. 124-137.

55 Srov. MCGARRIGLE - WALSH, Mindfulness..., s. 212-233.

56 Srov. PAULÍK, K otázce..., s. 293; Jana STEJSKALOVÁ, Krize sociální práce aneb máme to ještě ve svých rukou?, Sociální práce / 
Mindfulness může být pro sociální pracovníky kreativní a použitelný nástroj. Dovede významně snižit hladinu stresu a efektivněji balancovat mezi požadavky, kterým člověk v životě čelí. Sociální pracovníci mohou všímavost využívat např. pro předcházení syndromu vyhoření a zvyšování uvědomělosti. ${ }^{57}$ Trénování všímavosti může přinést mnoho benefitů nejen pro osobnost sociálního pracovníka, ale i pro jeho praxi. ${ }^{58}$ Jde např́klad o: zvýšení pracovního výkonu, resp. efektivity práce, zlepšení komunikace a řešení problémů, zvýšení koncentrace a soustř̌edění, zvýšení schopnosti zvládat konflikty, dosažení rovnováhy a odolnosti na pracovišti i v domácím prostředí, zlepšení srozumitelnosti a posílení kreativního myšlení, podporování psychické a fyzické pohody, snižování hladiny stresu, předcházení syndromu vyhoření a emocionálnímu vyčerpání, redukování automatických a navyklých reakcí (resp. schopnost rozhodovat se více uvědoměle), redukování chronických bolestí, zlepšení energetické hladiny, zvýšení kontroly v př́ípadě dlouhodobých úzkostných poruch, zlepšení profesionální praxe a pracovních vztahů. ${ }^{59}$ Je však nutné si uvědomit, že praxe všímavosti souvisí s určitou disciplínou - čili dodržováním konkrétních a nutných zásad ze strany sociálních pracovníků. Tyto jsou klíčovým předpokladem k čerpání pozitivních důsledků praxe mindfulness a ve článku byly nastíněny.

Nebyly opomenuty ani možnosti, jak mohou sociální pracovníci rozvíjet, zdokonalovat a udržovat všímavost, a využít tak její potenciál pro rozvoj osobnosti. $\mathrm{K}$ tomu jim mohou dobře posloužit pojednávané kurzy, resp. tréninky všímavosti MBSR či MBCT, které se do velké míry překrývají. Sociální pracovníci navíc mohou projít tréninkem sami, s oporou knižních zdrojů (tj. autodidakticky).

Nakonec bylo pojednáno o „odvrácené tváři mindfulness“, tedy některých rizicích, která mohou být $\mathrm{s}$ praktikováním spojena. Vzhledem $\mathrm{k}$ nedostatku vědeckých poznatků o rizicích je však zapotř̌ebí, aby jim byla nadále věnována důkladná pozornost a zdroje přibližující potenciální úskalí všímavosti se více rozšírily.

Všímavost má, jakožto potenciální nástroj rozvoje osobnosti sociálního pracovníka, rozhodně velký potenciál a lze předpokládat, že jejím blahodárným důsledkům v rozvoji osobnosti bude věnováno stále více výzkumů. 


\title{
V̌̌ímavost (mindfulness) jako potenciální nástroj rozvoje osobnosti sociálního pracovníka
}

\begin{abstract}
Abstrakt
Předkládaný příspěvek představuje všímavost (angl. mindfulness) jako potenciální nástroj rozvoje osobnosti sociálního pracovníka, jehož prostřednictvím Ize efektivně udržovat duševní a potažmo tělesné zdraví v kondici. Nejdříve je všímavost přiblížena skrze interpretace různých autorů. Její perspektivnost je dále podložena výsledky různých vědeckých výzkumů. Představen je rovněž současný stav rozvíjení všímavosti v sociální práci včetně tradičních, oficiálních kurzů všímavosti (MBSR, MBCT), prostřednictvím kterých ji Ize rozvíjet, zdokonalovat a udržovat. Nakonec je věnován prostor též "odvrácené tváři všímavosti", tj. rizikům, která mohou být s jejím praktikováním spojena.
\end{abstract}

Klíčová slova: sociální práce, sociální pracovník, všímavost, mindfulness, osobnost, rozvoj

\section{Kontakt}

\section{Mgr. Michal Kaczor}

Jihočeská univerzita v Českých Budějovicích

Teologická fakulta, Katedra etiky, psychologie a charitativní práce

Kněžská 8, 37001 České Budějovice

info@michalkaczor.cz 